\title{
ЩОДО ПРАВОВОГО СТАТУСУ АЗОВСЬКОГО МОРЯ ТА КЕРЧЕНСЬКОÏ ПРОТОКИ
}

\author{
УСТИМЕНКО Богдан Миколайович - магістр права, адвокат \\ https://orcid.org/0000-0001-9151-9438 \\ УСТИМЕНКО Тетяна Петрівна - кандидат юридичних наук, доцент, \\ професор кафедри цивільного права і процесу Національної академії внутрішніх \\ справ
}

https://orcid.org/0000-0003-0049-5608 DOI:10.32782/NP.2019.4.21

Стаття присвячена визначенню правового статусу Азовсъкого моря та Керченсъкої протоки, а також аналізу Договору між Україною та Російсъкою Федерацією про співробітництво у використанні Азовсъкого моря і Керченсъкої протоки.

Ключові слова: Азовсъке море, Керченсъка протока, внутрішні води, Керченсвкий Договір, право транзитного проходу, міжнародне судноплавство.

24.12.2003 Президент України $\lambda$. Кучма та Президент Російської Федерації В. Путін підписали в українському місті Керч документ під назвою «Договір між Україною та Російською Федерацією про співробітництво у використанні Азовського моря і Керченської протоки» ${ }^{1}$ (далі - Керченський Договір).

Стаття 2 Керченського Договору містить наступні приписи:

1. Торговельні судна та військові кораблі, а також інші державні судна під прапором України або Російської Федерації, що експлуатуються в некомерційних цілях, користуються в Азовському морі та Керченській протоці свободою судноплавства;

2. Торговельні судна під прапорами третіх держав можуть заходити в Азовське море і проходити Керченською протокою,

\footnotetext{
1 Договір між Україною та Російською Федерацією про співробітництво у використанні Азовського моря і Керченської протоки: Договір від 24.12.2003 p. URL: // https://zakon.rada.gov.ua/laws/ show/643 205.
}

якщо вони прямують до українського або російського порту чи повертаються з нього;

3. Військові кораблі або інші державні судна третіх держав, що експлуатуються в некомерційних цілях, можуть заходити в Азовське море та проходити Керченською протокою, якщо вони прямують 3 візитом чи діловим заходженням до порту однієї із Сторін на іiі запрошення або дозвіл, погоджений з іншою Стороною.

Тобто Керченським Договором, серед іншого, визначено, що військові кораблі або інші державні судна третіх держав, що експлуатуються в некомерційних цілях, не можуть на запрошення України заходити в Азовське море та проходити Керченською протокою без згоди Російської Федерації.

Також в абзаці першому статті 1 Керченського Договору зазначено, що Азовське море та Керченська протока історично $є$ внутрішніми водами України і Російської Федерації.

Враховуючи це твердження у Керченському Договорі, вбачаємо за слушне звернути увагу на деякі дійсно історичні факти.

Так, близько 150 тисяч років до н.е. у Криму були розташовані знайдені археологами неандертальські поселення.

Першими відомими за назвами народами Криму були кіммерійці і таври (I тис. до н. е).

У VII - V століттях до н.е. грецькі колоністи засновують на території Криму поселення Пантікапей (на території сучасної Керчі), Херсонес (на території сучасного 
Севастополя), Керкінітиду (на території сучасної Свпаторії), Феодосію та інші населені пункти.

Проходили століття. На Кримському півострові з'являлися та зникали народи, культури та міста. Регіон став останнім притулком для скіфської державності - 3 II ст. до н. е. до III ст. н. е. в Криму існувала пізньоскіфська держава із столицею у Неаполі Скіфському (територія сучасного Сімферополя). У різні часи на Крим поширювалася влада Римської імперії, готів, гунів, Візантії, хозарів, печенігів, половців та інших народів. Східний Крим, ймовірно, входив у X-XI століттях до складу Тмутараканського князівства, яке було частиною Київської Русі.

У XIII столітті монгольське військо хана Батия підпорядковує Крим собі. Півострів стає складовою Золотої Орди.

З 1441 по 1783 роки (близько 350 років) у Криму, Північному Приазов'ї та Причорномор'ї існувала держава кримських татар під назвою «Кримське ханство».

У 1783 році Російська імперія анексуе Кримське ханство. Кримський півострів залишається у складі імперії 134 роки, яка у 1917 році припинила своє існування як суб'єкт міжнародного права.

Щодо історії використання Азовського моря та Керченської протоки необхідно стисло зазначити наступне.

Керченська протока у давні часи мала назву Босфор Кіммерійський.

Загальновідомим $є$ те, що греки називали Азовське море Меотійським озером, римляни - Меотійським болотом, меоти Темеринда, араби - Бараль-Азов, турки Бахр-Ассак, слов'яни називали море Синім i, за іншою версією, Сурозьким, генуезці та венеціанці - Mare Tane тощо. Кожний народ, який проживав на території Кримського півострова, сучасних Херсонської, Запорізької, Донецької, Ростовської областей та Краснодарського краю, використовуючи Азовське море, давав йому власну назву.

3 часів Середньовіччя генуезці та венеціанці почали складати лоції і морські карти Азовського моря.

Отже, тисячі років Азовське море (Меотійське озеро, Меотійське болото, Темеринда, Бараль-Азов, Бахр-Ассак, Сурозьке море,
Mare Tane тощо) використовувалося багатьма народами, що підтверджується чисельними доказами.

Цікавим $є$ також те, що Азовське море $є$ найменшим за глибиною у світі та одночасно найбільш континентальним - найвіддаленішим від океану.

З 1921 по 1954 роки Крим входив до Російської Радянської Федеративної Соціалістичної Республіки у складі Союзу Радянських Соціалістичних Республік. Водночас, між Краснодарським краєм і Кримською АСРP був визначений адміністративний кордон у Керченський протоці, про що свідчать радянські документи.

На підставі Закону Верховної Ради Союзу Радянських Соціалістичних Республік «Про передачу Кримської області зі складу РРФСР до складу УРСР» ${ }^{2}$ Кримська область була передана зі складу РРФСР до складу УРСР. Кордон по морю між республіками відображали навіть на деяких картах друкарським способом.

12.06.1990 3'їзд Народних Депутатів Російської Радянської Федеративної Соціалістичної Республіки проголосив державний суверенітет Російської Радянської Федеративної Соціалістичної Республіки ${ }^{3}$.

24.08.1991 Верховна Рада УРСР проголосила незалежність України та створення самостійної української держави - України

На завершення нашого стислого історичного екскурсу необхідно також звернути увагу на Угоду про створення Співдружності Незалежних Держав ${ }^{5}$ (далі - Біловезька Угода). Як було констатовано у Біловезькій

\footnotetext{
2 Про передачу Кримської області зі складу РРФСР до складу УРСР: Закон від 26.04.1954 р. URL: // https://archives.gov.ua/Sections/Crimea 50/ photos_03.php?3.

${ }^{3}$ О государственном суверенитете Российской Советской Федеративной Социалистической Республики: Декларация СНД РСФСР от 12.06.1990 г.№ 22-1. URL: // https://legalacts.ru/doc/deklaratsijasnd-rsfsr-ot-12061990-n-22-1/.

4 Про проголошення незалежності України: Постанова Верховної Ради Української РСР від 24.08.1991 p. URL: // https://zakon.rada.gov.ua/laws/ show/1427-12.

${ }^{5}$ Угода про створення Співдружності Незалежних Держав(укр/рос):Угодавід08.12.1991 р.(ратифікація від 10.12.1991р.) URL: // https://zakon.rada.gov.ua/ laws/show/997 077 .
} 


\section{Міжнародне право}

Угоді, Союз Радянських Соціалістичних Республік як суб'єкт міжнародного права i геополітична реальність припиняє своє існування. Тобто Біловезькою Угодою поставлена історична «крапка»у «житті» наддержави минулого - Радянського Союзу.

3 викладених вище фактів стає зрозумілим, що з часів проживання неандертальців у Тавриді-Криму (приблизно 150 тисяч років до н.е.) до поточного 2020 року держави 3 назвами «Україна» та «Російська Федерація» користуються водами Азовського моря та Керченської протоки лише неповних 30 років.

Отже, на загальному історичному тлі, а також враховуючи сукупність загальновідомих фактів, твердження про певну «історичну належність» вод Азовського моря та Керченської протоки, що міститься у Керченському Договорі, є відхиленням від істини.

Необхідно також зазначити, що твердження у Керченському Договорі про те, що Азовське море та Керченська протока є «внутрішніми водами України і Російської Федерації» вочевидь не відповідають приписам Конвенції Організації Об'єднаних Націй 3 морського права 1982 року $^{6}$ (далі - Конвенція з морського права), сторонами якої 6 як Україна, так і РФ, оскільки внутрішні води можуть належати одній державі, а не двом, що прямо підтверджується змістом статей 8 та 10 Конвенції з морського права.

Окрім цього, статтею 8 Конвенції з морського права встановлено, що лише води, розташовані в бік берега від вихідної лінії територіального моря, складають частину внутрішніх вод.

Отже, Азовське море та Керченська протока не є «внутрішніми водами» ні України, ні РФ, ні двох держав одночасно. Як слідство, абзац перший статті 1 Керченського Договору прямо суперечить статтям 8 та 10 Конвенції з морського права.

\footnotetext{
6 Конвенция Организации Объединенных Наций по морскому праву (ратифікована Законом України «Про ратифікацію Конвенції Організації Об’єднаних Націй з морського права 1982 року та Угоди про імплементацію Частини XI Конвенції Організації Об'єднаних Націй з морського права 1982 року» № 728-XIV від 03.06.1999р.) URL: // https://zakon.rada.gov.ua/laws/show/995 057.
}

Також в абзаці другому статті 1 Керченського Договору зазначено, що Азовське море розмежовується лінією державного кордону відповідно до угоди між Сторонами.

Необхідно звернути увагу на те, що після набуття незалежності Україна наполягала на поділі простору Азово-Керченської акваторії та встановленні делімітаційної лінії, в тому числі у Чорному морі, відповідно до Конвенції з морського права.

Так, у 1992 році, у відповідь на запрошення Генерального Секретаря Організації Об'єднаних Націй взяти участь у Конвенції 3 морського права, Україною було передано до Організації Об'єднаних Націй перелік географічних координат точок, які визначають вихідні лінії для виміру ширини територіального моря, виключної економічної зони та континентального шельфу в Чорному та Азовському морях.

Однак, не дивлячись на 36 раундів переговорів між Україною та РФ, які тривали 3 перервами $з$ 16.10.1996 по 03.03.2011, Азово-Керченська акваторія не була розмежована державним або морським кордоном, оскільки російська сторона не виявляла бажання встановлювати кордон згідно із Конвенцією з морського права та навмисно затягувала переговори.

Окрім цього, РФ відмовлялася здійснювати делімітацію Азово-Керченської акваторії на основі республіканських кордонів, вказаних у радянських картах.

Також є всі підстави вважати, що укладення у 2003 році Керченського Договору було наслідком примусу України шляхом погрози силою або їі застосування з боку РФ.

Так, у вересні 2003 року російська сторона спровокувала дуже серйозну кризу у відносинах з Україною шляхом протиправного, несанкціонованого українською стороною будівництва насипної дамби у Керченській протоці між російським Таманським півостровом та українським островом Коса Тузла. Ще тоді Російська Федерація мала намір фактично порушити територіальну цілісність України та недоторканності їі кордонів.

Ситуація була настільки критичною, що навіть український парламент, з метою за- 
безпечення належного контролю за режимом державного кордону України в районі острова Коса Тузла та прилеглій акваторії Керченської протоки, діяльністю органів державної влади та посадових осіб щодо забезпечення територіальної цілісності України та недоторканності ії кордонів, постановив утворити Тимчасову спеціальну комісію Верховної Ради України щодо забезпечення парламентського контролю за режимом державного кордону України в районі острова Коса Тузла7.

Загальновідомо, що з метою уникнення міждержавного збройного конфлікту, кровопролиття та смертей тисяч українських громадян, Президент України $\lambda$. Кучма був змушений особисто втрутитися у конфлікт навколо острова Коса Тузла та підписати 3 Президентом РФ В. Путіним дуже сумнівний 3 юридичної та фактичної точок зору Керченський Договір. Пізніше Верховна Рада України за поданням $\lambda$. Кучми постановила ратифікувати Керченський Договір

Але після підписання Керченського Договору гостра фаза конфлікту між Україною та РФ зникне лише на 10 років. 3 лютого 2014 року РФ повністю окупувала територію Кримського півострова, а також прилеглі до нього українські морські акваторії, загальна приблизна площа яких дорівнюе 100 тисяч квадратних кілометрів.

У світлі вищевикладеного інциденту навколо українського острову Коса Тузла та, як його наслідок, укладення Керченського Договору, необхідно звернути особливу увагу на припис статті 52 Віденської конвенції про право міжнародних договорів 1969 року ${ }^{9}$.

\footnotetext{
Про утворення Тимчасової спеціальної комісії Верховної Ради України щодо забезпечення парламентського контролю за режимом державного кордону України в районі острова Коса Тузла: Постанова Верховної ради України від 23.10.2003 р. URL: https://zakon.rada.gov.ua/laws/show/1235-15.

${ }^{8}$ Про ратифікацію договору між Україною та Російською Федерацією про співробітництво у використанні Азовського моря і Керченської протоки: Закон України від 20.04.2004 p. URL: https://zakon. rada.gov.ua/laws/show/1682-15.

${ }^{9}$ Віденська Конвенція про право міжнародних договорів: Конвенція від 23.05.1969 p. URL: https:// zakon.rada.gov.ua/laws/show/995 118.
}

Згідно із цим приписом договір є неважним (російською мовою - «ничтожным»), якщо його укладення стало результатом погрози силою або іiї застосування на порушення принципів міжнародного права, втілених у Статуті Організації Об'єднаних Націй.

Отже, з огляду на припис статті 52 Biденської конвенції про право міжнародних договорів та фактичні обставини укладення Керченського Договору, можна дійти до висновку, що Керченський Договір не має юридичної сили.

Щодо правого статусу Азово-Керченської акваторії необхідно зазначити наступне.

Азовське море $є$ напівзамкнутим відповідно до статті 122 Конвенції з морського права.

Загальна площа Азовського моря дорівнює 37600 квадратних кілометрів, його максимальна довжина дорівнює 224 милі, максимальна ширина - 109 миль.

E фактом, що площа цього моря $є$ вочевидь достатньою для того, щоб містити як територіальне море двох прибережних держав - України та РФ, так і їх виключні економічні зони.

У свою чергу, Керченська протока, враховуючи ії ширину, містить територіальне море як України, так і РФ.

Водночас, Керченська протока $\epsilon$ міжнародною протокою на підставі статті 37 Конвенції з морського права, оскільки вона безпосередньо з'єднує виключні економічні зони Азовського та Чорного морів.

Враховуючи все вище викладене, а також приписи статей 38 та 44 Конвенції 3 морського права, усі судна та літальні апарати, у тому числі третіх держав (а не тільки України або РФ), можуть користуватися правом транзитного проходу Керченською протокою, якому не повинно чинитися перешкод, та заходити в Азовське море.

Також на підставі статті 52 Віденської конвенції про право міжнародних договорів Україна може повідомити всі держави світу та інших відповідних суб'єктів міжнародного права про те, що Керченський Договір не має юридичної сили. 


\section{Аітература}

1. Договір між Україною та Російською Федерацією про співробітництво у використанні Азовського моря i Керченської протоки: Договір від 24.12.2003 p. URL: // https://zakon.rada. gov.ua/laws/show/643_205.

2.Про передачу Кримської області зі складу РРФСР до складу УРСР: Закон від 26.04.1954 p.URL:// https://archives.gov.ua/ Sections/Crimea_50/photos_03.php?3.

3 . О государственном суверенитете Российской Советской Федеративной Социалистической Республики: Декларация СНД РСФСР от 12.06.1990 г

№ 22-1. URL: // https://legalacts.ru/doc/ deklaratsija-snd-rsfsr-ot-12061990-n-22-1/.

4. Про проголошення незалежності України: Постанова Верховної Ради Української РСР від 24.08.1991 p. URL:// https:// zakon.rada.gov.ua/laws/show/1427-12.

5. Угода про створення Співдружності Незалежних Держав (укр/рос): Угода від 08.12.1991 р. (ратифікація від 10.12.1991 p.) URL:// https://zakon.rada.gov.ua/laws/ show/997_077.

$6 . \quad$ Конвенция Организации Объединенных Наций по морскому праву (ратифікована Законом України «Про ратифікацію Конвенції Організації Об’єднаних Націй з морського права 1982 року та Угоди про імплементацію Частини ХI Конвенції Організації Об'єднаних Націй з морського права 1982 року» № 728-XIV від 03.06.1999 p.) URL:// https://zakon.rada.gov.ua/laws/ show/995 057 .

7. Про утворення Тимчасової спеціальної комісії Верховної Ради України щодо забезпечення парламентського контролю за режимом державного кордону України в районі острова Коса Тузла: Постанова Верховної ради України від 23.10.2003 p. URL: // https://zakon.rada.gov.ua/laws/show/1235-15.

8. Про ратифікацію договору між Україною та Російською Федерацією про співробітництво у використанні Азовського моря і Керченської протоки: Закон України від 20.04.2004 p. URL: // https://zakon.rada.gov. ua/laws/show/1682-15.

\section{SUMMARY}

The article is devoted to determining the legal status of the Sea of Azov and the Kerch Strait and Agreement between Ukraine and Russian Federation on cooperation in the use of the Sea of Azov and the Kerch Strait analysis.

Keywords: the Sea of Azov, the Kerch Strait, internal waters, Kerch Agreement, right of transit passage, international navigation.

9. Віденська Конвенція про право міжнародних договорів: Конвенція від 23.05.1969 p. URL: // https://zakon.rada.gov.ua/laws/ show/995_118.

Ustymenko Bohdan, Ustymenko Tetiana.

The legal status of the Sea of Azov and the Kerch Strait

The article is devoted to determining the legal status of the Sea of Azov and the Kerch Strait and Agreement between Ukraine and Russian Federation on cooperation in the use of the Sea of Azov and the Kerch Strait (Kerch Agreement) analysis.

The authors of the article made three main conclusions:

1) The Kerch Strait and the Sea of Azov are not historic internal waters of Ukraine and Russian Federation;

2) The Agreement between Ukraine and Russian Federation on cooperation in the use of the Sea of Azov and the Kerch Strait is void in accordance with article 52 "Coercion of a State by the threat or use of force" of Vienna Convention on the law of treaties and due to the Russian aggressive provocation near the Tuzla island in 2003 that led the signing of the Kerch Agreement;

3) Under article 37 of the United Nation Convention on the Law of the Sea the Kerch Strait is an international strait. All ships and aircraft enjoy the right of transit passage of the Kerch Strait, which shall not be impeded.

Keywords: the Sea of Azor, the Kerch Strait, Kerch Agreement, internal waters, right of transit passage, international navigation. 